\title{
EVALUASI RUANG TERBUKA DI KAMPUS UNIVERSITAS BRAWIJAYA
}

\author{
Triandi Laksmiwati, Chairil Budiarto Amiuza, Wulan Astrini
}

Jurusan Arsitektur, Fakultas Teknik, Universitas Brawijaya

Alamatemail penulis : wulanastrini@ub.ac.id

\begin{abstract}
ABSTRAK
Evaluasi purna huni (EPH) ruang terbuka kampus bertujuan untuk menilai kenyamanan ruang, baik secara fisik maupun secara persepsi. Ruang terbuka yang menjadi studi kasus adalah lapangan dan gazebo di depan gedung rektorat Universitas Brawijaya (UB). Penelitian ini memadukan pendekatan kualitatif dengan metode survei, dengan instrumen utama rekaman foto, kuisioner, serta wawancara. Responden dipilih secara purposive. Data dari responden diolah untuk memperoleh gambaran perilaku pengguna ruang terbuka. Interpretasi dari hasil EPH dianalisis untuk memperoleh gambaran menyeluruh tentang efisiensi ruang terbuka bagi penggunanya. Hasil yang diperoleh menunjukkan bahwa gazebo kurang dapat mengakomodasi kenyamanan pengguna ruang terbuka kampus UB pada aspek privasi dan persepsi. Aspek interaksi dapat mengakomodasi kenyamanan pengguna gazebo dengan baik (lebih dari 50\%), sedangkan aspek orientasi dinilai cukup dapat mengakomodasi (50\%). Ruang terbuka kampus UB berupa lapangan rektorat masih kurang dapat mengakomodasi kenyamanan pengguna ruang terbuka kampus, baik dari aspek privasi, interaksi, persepsi, maupun orientasi, dimana setiap aspek tersebut nilai evaluasinya kurang dari 50\%.
\end{abstract}

Kata kunci: EPH, ruang terbuka, kampus

\begin{abstract}
The post occupancy evaluation (POE) of campus open space aimed to asses comfort space both physically and perceptionally. Open spaces choosen as case study are court and gazebo in front of rectorate building of Brawijaya University. This study combines qualitative approaches with a survey method. The research instruments are photos, questionnaires, and interviews. Respondents in this study were selected by purposive sampling. Data obtained from respondents were processed to obtain description of the behavior of open space users. Interpretation of the results was analyzed in order to obtain an overall description of the space efficiency for its users. The results obtained indicate that gazebo unable to accomodate users' comfort of campuss open space of UB on privacy and perception aspects. Besides, interaction aspect of gazebo able to accomodate users' comfort of campus open space of UB in good level (more than 50\%), while orientation aspect able to accomodate it in medium level (50\%). The court is unable to accomodate users' comfort (less than 50\%).
\end{abstract}

\section{Pendahuluan}

Keywords: POE, open space, campus

Area fisik kampus memberikan sense of identity dan social focus. Akademik karakter diekspresikan dalam bentuk bangunan dan pola spasialnya, hirarki dari bentuk terbangun dan pola spasial kampus, serta susunan dari koneksi spasial yang merefleksikan misi dan 
organisasi dari universitas atau fakultas. Kampus Universitas Brawijaya (UB) belum memiliki perencanaan yang merefleksikan skala waktu yang panjang dan meliputi hubungan antara desain kampus dan misi akademik yang dapat menciptakan komunitas akademik dan lingkungan pembelajaran yang hidup sepanjang waktu.

Permasalahan kampus UB kini antara lain pada pengembangan kapasitas pengguna dan diversifikasi fakultas/jurusan, sedangkan lahannya terbatas. Akibatnya ruang terbuka tidak memadai. Area dan bentuk fisik kampus tidak mencerminkan identitas dan sosial akademik, "sense of place" jurusan, dan misi organisasi universitas/fakultas/jurusan. Untuk itu diperlukan evaluasi menyeluruh dan terpadu antara kapasitas lahan, kondisi fisik, dan ruang terbukanya. Terkait hal tersebut, evaluasi purna huni ruang terbuka hijau kampus menjadi satu hal yang mendesak dan penting dilakukan.

\section{Bahan dan Metode \\ 2.1 Evaluasi Purna Huni}

Evaluasi purna huni (EPH) merupakan pengujian efektivitas sebuah lingkungan binaan bagi kebutuhan manusia, baik pengujian efektivitas bangunannya sendiri maupun efektivitas programnya terhadap kebutuhan pengguna (Zimring dan Reizenstein, 1981 dalam Laurens, 2004:202). Lingkungan binaan tersebut juga merupakan behavior setting yang memiliki unsur-unsur berupa sekelompok orang yang melakukan sesuatu kegiatan, aktivitas, atau perilaku dari sekelompok orang tersebut; tempat dimana kegiatan tersebut dilakukan; serta waktu spesifik saat kegiatan tersebut dilaksanakan (Haryadi dan Setiawan, 2010:27). Ruang luar kampus yang menjadi objek penelitian ini merupakan bentuk lingkungan binaan yang juga berperan sebagai setting bagi perilaku manusia (pengguna) di dalamnya.

Preiser (1988) dalam Haryadi dan Setiawan (2010:27) menjelaskan tentang elemen-elemen yang dapat diidentifikaasikan dan diaplikasikan dalam EPH, yaitu:

1. Elemen teknis: aspek kesehatan, keselamatan, dan keamanan bangunan.

2. Elemen fungsional: kemampuan penghuni mengoperasikan bangunan.

3. Elemen perilaku: aspek sosial dan psikologis tingkat kepuasan penghuni bangunan.

\subsection{Perilaku dan Persepsi Lingkungan}

EPH menggunakan kebutuhan atau program pengguna sebagai kriteria atau tolok ukur keberhasilan lingkungan, mengandalkan kesimpulannya pada kesan pengguna dan hasil survey atau pengamatan (Laurens, 2004:224). Oleh sebab itu, perilaku pengguna ruang terbuka kampus merupakan variabel utama pengamatan untuk mengetahui keberhasilan desain setting tersebut. Menurut Laurens (2004:1) perilaku menunjukkan manusia dalam aksinya, berkaitan dengan semua aktivitas manusia secara fisik; berupa interaksi manusia dengan sesamanya ataupun dengan lingkungan fisiknya.

Persepsi lingkungan adalah interpretasi tentang suatu setting oleh individu, didasarkan pada latar belakang budaya, nalar, dan pengalaman individu tersebut (Haryadi dan Setiawan, 2010:29). Menurut Laurens (2004:57) persepsi bukanlah sekedar pengindraan, persepsi sebagai penafsiran pengalaman (the interpretation of experience). Persepsi lingkungan dalam penelitian ini dibatasi pada aspek teritorialitas dan kesesakan (crowding). 
Teritorialitas merupakan pola tingkah laku yang ada hubungannya dengan kepemilikan atau hak seseorang atau sekelompok orang atas suatu tempat atau suatu lokasi geografis (Laurens, 2004:125). Altman (1980) dalam (Laurens, 2004:126-127) mengklasifikasikan teritori menjadi tiga macam, yaitu:

1. Teritori primer: tempat-tempat yang sangat pribadi sifatnya dan hanya boleh dimasuki oleh orang-orang yang sudah sangat akrab atau yang sudah mendapat izin khusus.

2. Teritori sekunder: tempat-tempat yang dimiliki bersama oleh sejumlah orang yang sudah cukup saling mengenal dan kendali pada teritori ini tidaklah sepenting teritori primer serta kadang berganti pemakai atau berbagi penggunaan dengan orang asing.

3. Teritori publik: tempat-tempat yang terbuka untuk umum, dimana setiap orang diperkenankan untuk berada di tempat tersebut.

Menurut Laurens (2004:149) kesesakan (crowding) mengacu pada pengalaman seseorang terhadap jumlah orang di sekitarnya atau persepsi terhadap kepadatan. Loo (1977) dalam Hariyadi dan Setiawan (2010:44) mengklasifikasikan determinan kesesakan menjadi tiga, yaitu:

1. Faktor lingkungan, meliputi faktor fisik (dimensi, tempat, densitas, dan suasana ruang/tempat) dan faktor sosial (norma, kultur, dan adat istiadat).

2. Faktor situasional, meliputi karakteristik hubungan antar individu, lama, serta intensitas kontak.

3. Faktor intrapersonal, meliputi karakteristik dari seseorang seperti usia, jenis kelamin, pendidikan, pengalaman, dan sikap.

\subsection{Ruang Luar Kampus}

Ruang luar kampus merupakan ruang yang memiliki karakter terbuka dan terletak di luar massa bangunan, dimanfaatkan untuk kegiatan terbatas dan keperluan khusus. Ruang luar dapat memiliki fungsi sosial dan fungsi ekologis (Hakim dan Utomo, 2003:52). Dalam evaluasi purna huni ini, ruang luar kampus berperan sebagai behavior setting sehingga fungsinya diutamakan pada fungsi sosial yang terkait dengan aktivitas penggunanya, yaitu tempat bermain dan olahraga; tempat komunikasi sosial; tempat peralihan dan menunggu; tempat untuk mendapatkan udara segar; sarana penghubung satu tempat dengan tempat lainnya atau pembatas antar massa bangunan; sarana penelitian dan pendidikan serta penyuluhan bagi masyarakat untuk kesadaran lingkungan; dan sarana menciptakan kebersihan, kesehatan, keserasian, dan keindahan lingkungan.

Unsur-unsur ruang luar adalah batasan ruang, macam ruang, sirkulasi, serta pencapaian (Hakim dan Utomo, 2003:42-49). Batasan ruang merupakan elemen pembatas untuk perlindungan, membentuk ruang paling terasa, pembentuk pola sirkulasi, pola pengarah, dan penutup tanah. Macam ruang yaitu berbentuk lorong, linier, geometris, dan mekanis (dipaksakan). Sirkulasi terkait dengan pola penempatan aktivitas dan pola penggunaan tanah, sehingga merupakan pergerakan dari ruang yang satu ke ruang yang lain. Pencapaian terdiri dari pencapaian frontal, pencapaian langsung mengarah dan lurus ke objek ruang yang dituju, pencapaian ke samping, dan pencapaian memutar.

\subsection{Metode Penelitian}

Data diperoleh melalui kuesioner dan wawancara terbuka. Rsponden ditentukan dengan metode purposive sampling. Jumlah responden 200 orang. Jumlah ini diperoleh dari prosentase mahasiswa aktif UB yang diperkirakan sekitar 50\% dari total mahasiswa UB 
( $50 \%$ x $20.000=10.000$ orang). Sampel diambil sebanyak $2 \%$ dari jumlah tersebut. Kepada semua responden diinformasikan bahwa survei adalah evaluasi purna huni yang berkaitan dengan desain dan fungsi dari ruang terbuka kampus.

Data hasil kuisioner dan wawancara dianalisis yang memuat ketetapan tema umum dari wawancara dan tema-tema yang dikelompokkan berdasarkan pada kesamaan responsinya. Kualitas ruang secara fisik maupun secara persepsi menggunakan 4 (empat) skala Lickert. Data responden ditabulasi dan dipersentasikan secara sederhana, sehingga dapat diperoleh besaran responden. Kurang dari 50\% mengindikasikan tidak mewakili dan lebih dari 50\% mengindikasikan mewakili.

\section{Hasil dan Pembahasan}

\subsection{Ruang Terbuka Kampus Universitas Brawijaya}

Ruang terbuka utama kampus Universitas Brawijaya (UB) terletak di depan gedung Rektorat. Ruang terbuka ini digunakan oleh mahasiswa sebagai tempat diskusi/belajar, latihan olahraga, serta sebagai tempat penyelenggaraan acara sosial maupun budaya. Pada hari-hari penting nasional lapangan ini digunakan untuk upacara dan kegiatan formal lainnya. Di sebelah timur ruang terbuka ini terdapat bundaran Tugu Jam dengan posisi satu sumbu dengan gedung Rektorat.
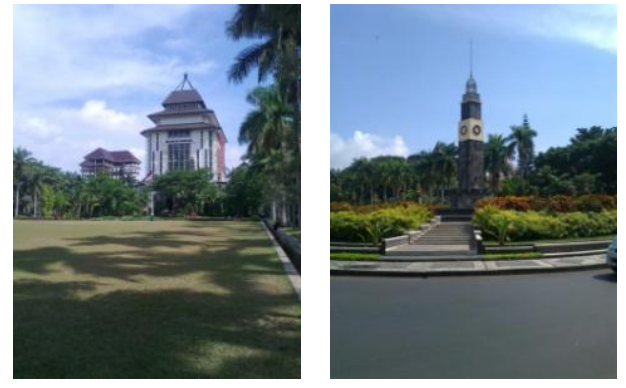

Gambar 1. Lapangan rektorat dan bundaran tugu jam Universitas Brawijaya

Di sebelah timur bundaran Tugu Jam terdapat ruang terbuka berupa gazebo melengkung. Ruang terbuka ini berbatasan dengan pedestrian dan jalur sirkulasi kendaraan. Bundaran menjadi area pemisah lapangan dan gazebo (gambar 2). Gazebo digunakan oleh mahasiswa untuk belajar, diskusi, atau sekedar nongkrong menunggu kuliah. Waktu pemakaian pagi hingga malam. Tempat ini dilengkapi dengan WiFi, tempat duduk, dan meja. Gazebo dinaungi pergola kayu dengan tanaman merambat di atasnya.
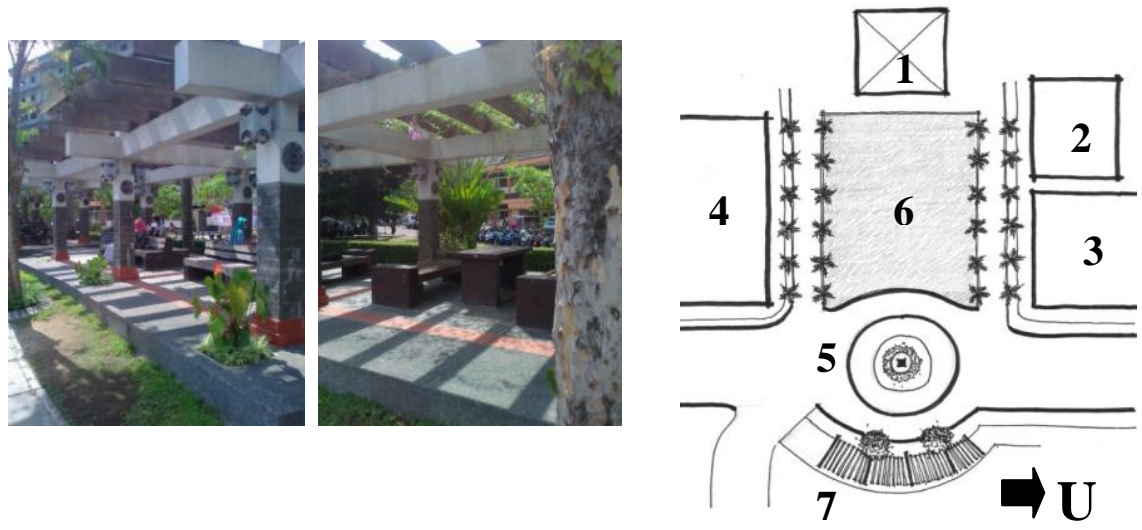

Keterangan:

1. Gedung Rektorat

2. Gedung Widyaloka

3. Gedung kuliah jurusan Ekonomi

4. Perpustakaan Pusat

5. Bundaran Tugu Jam

6. Lapangan (ruang terbuka 1)

7. Gazebo (ruang terbuka 2)

Gambar 2. Gambar dan lokasi lapangan dan gazebo 


\subsection{Deskripsi Karakteristik Umum Responden dan Hasil Observasi \\ 3.2.1 Karakteristik umum responden}

Responden penelitian ini sejumlah 200 orang. 91 orang $(45,5 \%)$ laki-laki dan 109 orang (54,5\%) perempuan. Responden adalah mahasiswa UB dengan usia rata-rata 19-22 tahun. Variabel penilaian meliputi kecukupan ruang, cahaya, suara, cuaca, aroma, daya tarik estetik, keamanan, fleksibilitas guna, privasi, dan orientasi.

\subsubsection{Data hasil observasi di gazebo}

Layout gazebo berbentuk melengkung sesuai jalur pedestrian di depannya. Gazebo terbagi menjadi 3 (tiga) zona dengan jenis serta tatanan furnitur yang beragam, yaitu:

1. Zona 1: sepasang bangku yang saling berhimpitan di bagian belakang sandarannya serta sekelompok furnitur yang terdiri dari sebuah meja dengan bangku di kanan-kirinya.

2. Zona 2: 3 (tiga) kelompok furnitur yang terdiri dari sebuah meja dan bangku.

3. Zona 3: 2 (dua) kelompok furnitur terdiri dari 2 (dua) pasang bangku yang saling berhimpitan di bagian belakang sandarannya.

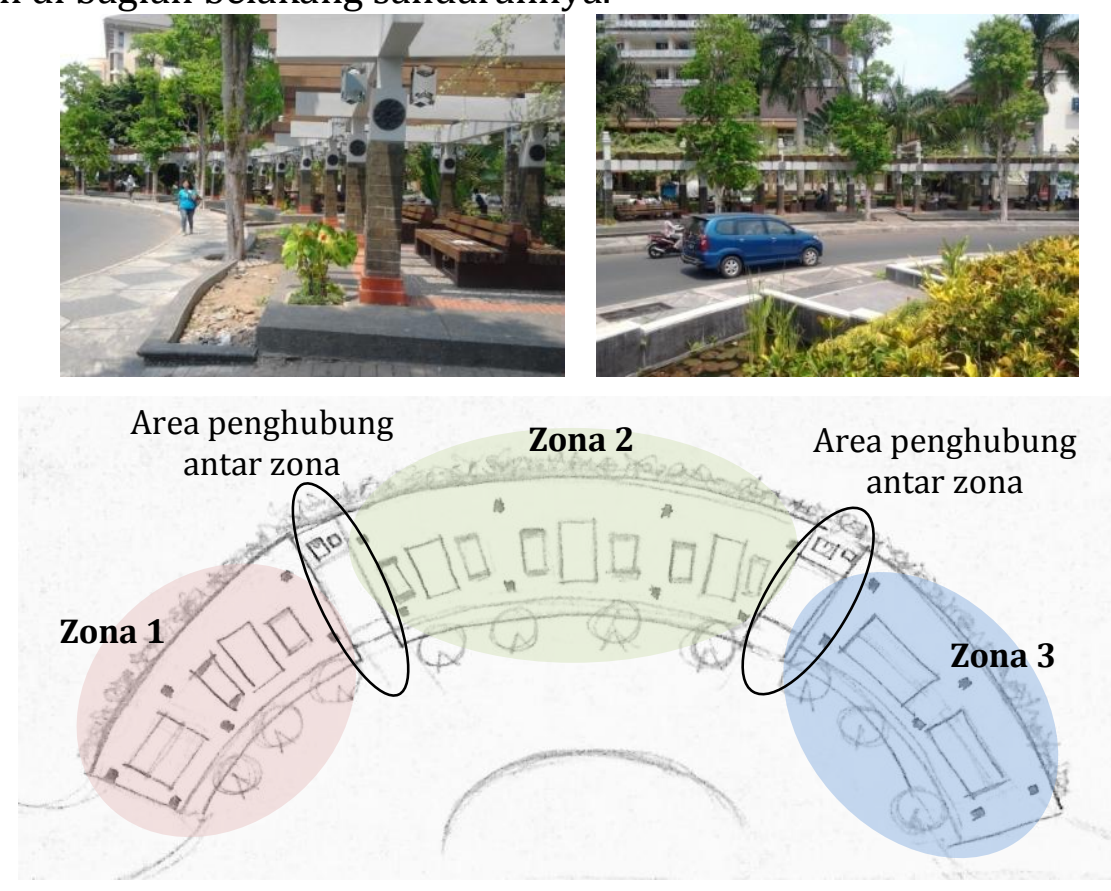

Gambar 3. Tampilan dan layout gazebo

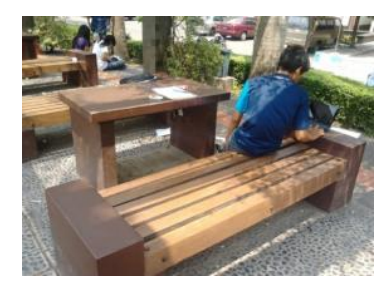

Kelompok furnitur: 1 meja \& 2 buah bangku di kanan-kirinya

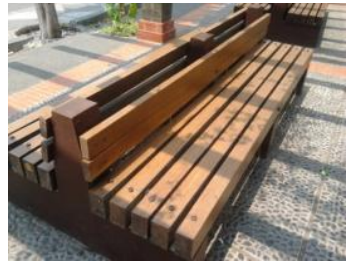

Kelompok furnitur: 2 buah bangku berhimpitan di bagian belakang sandaran

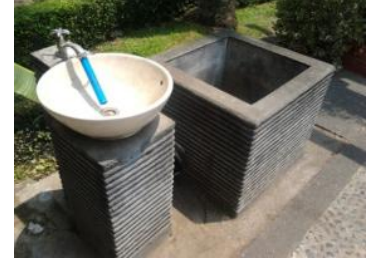

Wastafel dan bak sampah di area penghubung antar zona

Gambar 4. Ragam furnitur dan tatanannya di gazebo 


\section{A. Data responden}

Hasil kuisioner menunjukkan 79\% responden memilih beraktivitas di gazebo. Dari sejumlah responden tersebut, terdapat 44,3\% laki-laki dan 55,7\% perempuan. Aktivitas yang mereka lakukan adalah diskusi, belajar/mengerjakan tugas, browsing (wifi), dudukduduk, atau berkumpul dengan teman-teman. Berdasarkan hasil observasi diketahui bahwa mahasiswa paling banyak beraktivitas di gazebo di atas pukul 09.00 - 12.00 WIB $(54,4 \%)$. Di samping itu, dari seluruh responden yang beraktivitas di ruang terbuka ini juga diperoleh data tentang durasi waktu/lamanya waktu yang dihabiskan untuk beraktivitas (rata-rata dalam seminggu) yaitu $86,7 \%$ selama $0-4$ jam, 12\% selama $5-8$ jam, serta 1,3\% selama 9-12 jam.

\section{B. Data penilaian responden terhadap gazebo}

Data hasil kuisioner di gazebo dianalisis menurut persentase tertinggi di setiap variabel penilaian, sehingga diperoleh tingkatan penilaian terhadap gazebo seperti ditunjukkan dalam grafik berikut ini:

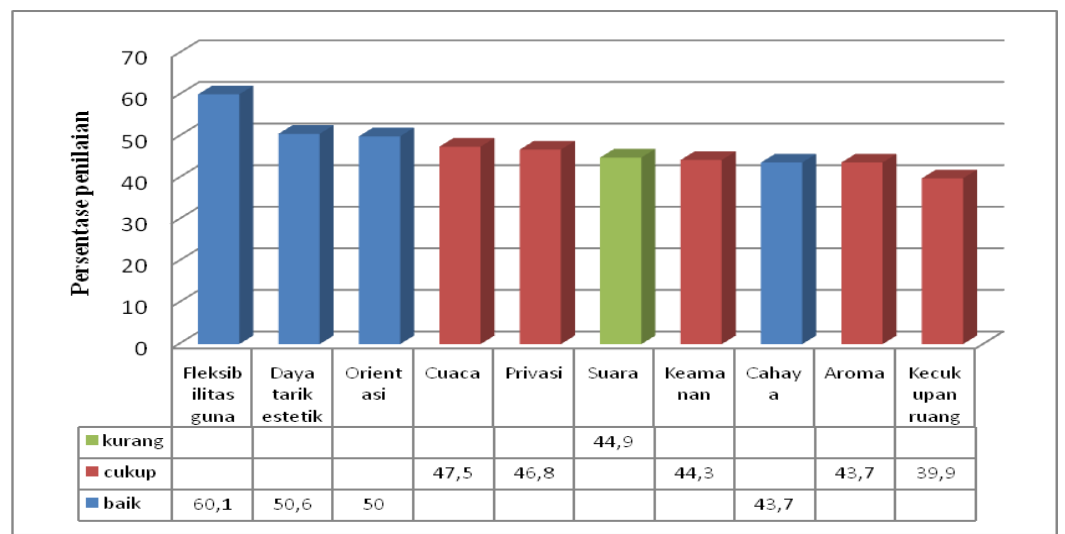

Gambar 5. Grafik tingkatan variabel penilaian ruang terbuka "gazebo"

Grafik di atas menunjukkan bahwa gazebo dinilai baik pada aspek fleksibilitas guna, daya tarik estetik, orientasi, serta cahaya. Sedangkan aspek cuaca, privasi, keamanan, aroma, serta kecukupan ruang dinilai cukup. Aspek yang dinilai paling kurang dari ruang terbuka berupa gazebo ini yaitu suara. Oleh sebab itu 40\% lapangan rektorat dinilai baik kualitas ruang terbukanya, 50\% cukup baik, dan 10\% kurang baik.

\subsubsection{Data hasil observasi di lapangan rektorat}

Lapangan rektorat ini terbagi menjadi 2 (dua) macam zona. Setiap zona memiliki suasana yang berbeda dan hal itu didukung oleh ragam vegetasi di dalamnya. Zona tersebut yaitu:

1. Zona 1: sisi kanan dan kiri area tiang bendera

2. Zona 2: lapangan rumput.

Lapangan bersifat terbuka. Jalur pedestrian di dalamnya merupakan penghubung antar zona. Jalur pedestrian di sisi utara menuju ke gedung Widyaloka, sedangkan yang di sisi selatan menuju ke perpustakaan pusat. 


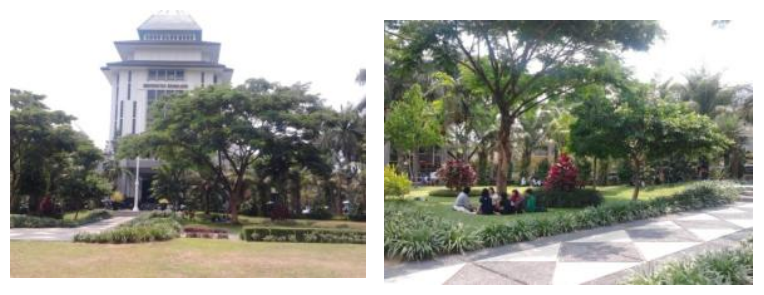

Suasana di zona 1

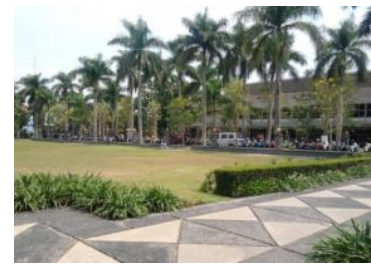

Suasana di zona 2

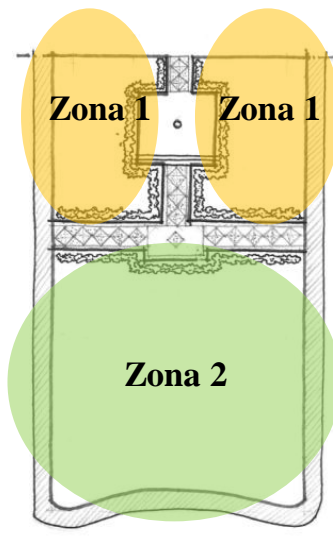

Key plan

\section{A. Data responden}

Hasil kuisioner menunjukkan bahwa 21\% responden memilih beraktivitas di lapangan rektorat. Dari sejumlah responden tersebut, terdapat 50\% laki-laki dan 50\% perempuan. Umumnya aktivitas yang mereka lakukan di ruang terbuka iniyaitu diskusi, olahraga, atau berkumpul dengan teman-teman. Berdasarkan hasil obsevasi diketahui bahwa mahasiswa paling banyak beraktivitas di lapangan rektorat di atas pukul $09.00-12.00$ WIB $(33,4 \%)$. Kondisi tersebut juga sama halnya dengan yang terjadi di gazebo. Rata-rata lamanya waktu beraktivitas dalam seminggu adalah 0-4 jam (88\% ) dan 5-8 jam (12\%).

\section{B. Data penilaian responden terhadap lapangan rektorat}

Data hasil kuisioner di lapangan rektorat dianalisis menurut persentase tertinggi di setiap variabel penilaian, sehingga diperoleh tingkatan penilaian terhadap gazebo seperti ditunjukkan dalam grafik berikut ini:

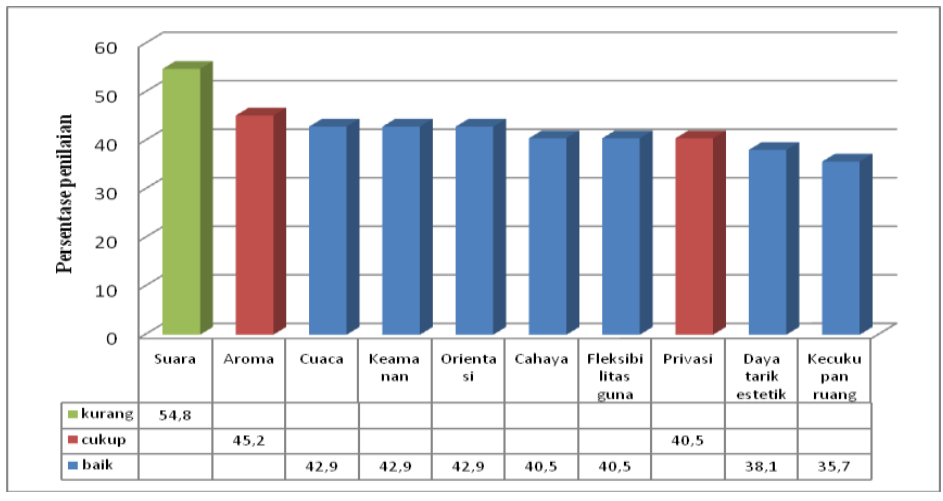

Gambar 7. Grafik tingkatan variabel penilaian ruang terbuka "lapangan rektorat"

Grafik di atas menunjukkan bahwa variabel yang dinilai kurang baik yaitu suara. Aspek yang dinilai baik oleh pengguna ruang terbuka lapangan rektorat meliputi cuaca, keamanan, orientasi, cahaya, fleksibilitas guna, daya tarik estetik, serta kecukupan ruang. Sedangkan aspek aroma dan privasi dinilai cukup. Oleh sebab itu 70\% lapangan rektorat dinilai baik kualitas ruang terbukanya, 20\% cukup baik, dan 10\% kurang baik. 
Sebagaimana telah diuraikan dalam data hasil observasi dan kuisioner di atas, maka 10 (sepuluh) variabel penilaian ruang terbuka kampus UB (gazebo dan lapangan rektorat) dapat dikelompokkan menjadi 4 (empat) faktor untuk dianalisis, yaitu sebagai berikut:

1. Privasi, meliputi privasi (fisik; visual) serta keamanan (dari kejahatan dan kendaraan).

2. Interaksi, meliputi fleksibilitas guna (multifungsi ruang).

3. Persepsi, meliputi kecukupan ruang (lega; sesak), cahaya (terang; gelap; silau), aroma, suara (kebisingan; keheningan), cuaca (kepanasan; kedinginan), serta daya tarik estetik (indah; menarik; menyenangkan).

4. Orientasi, meliputi orientasi (bebas; terbatas)

\subsubsection{Evaluasi purna huni gazebo}

\section{A. Privasi}

Tatanan-tatanan kelompok furnitur secara linier menciptakan ruang-ruang privasi. Kondisi tersebut juga didukung keberadaan 4 (empat) kolom yang membingkai setiap kelompok tatanan furnitur. Analisis ruang-ruang privasi tersebut dijelaskan melalui gambar berikut ini:

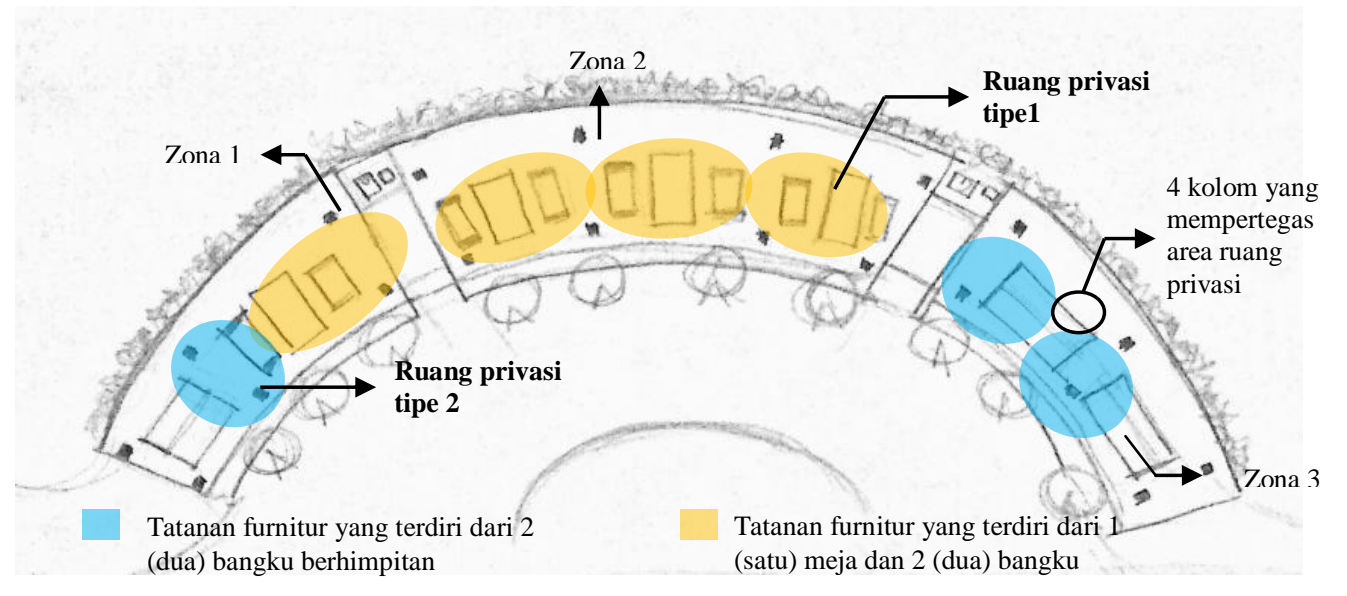

Gambar 8. Ruang-ruang privasi pada gazebo

Sirkulasi yang ada di dalam gazebo maupun jalur pedestrian yang membatasi gazebo dengan sirkulasi kendaraan dapat mempengaruhi kenyamanan ruang-ruang privat. Berdasarkan teori yang dikemukakan oleh Hakim \& Utomo (2003:43), maka sirkulasi yang ada di dalam gazebo merupakan jalur sirkulasi melalu antar ruang, dimana integritas yang kuat bagi setiap ruang-ruang di dalamnya serta bentuk alurnya cukup fleksibel. Pola sirkulasi tersebut ditunjukkan dalam gambar berikut ini: 


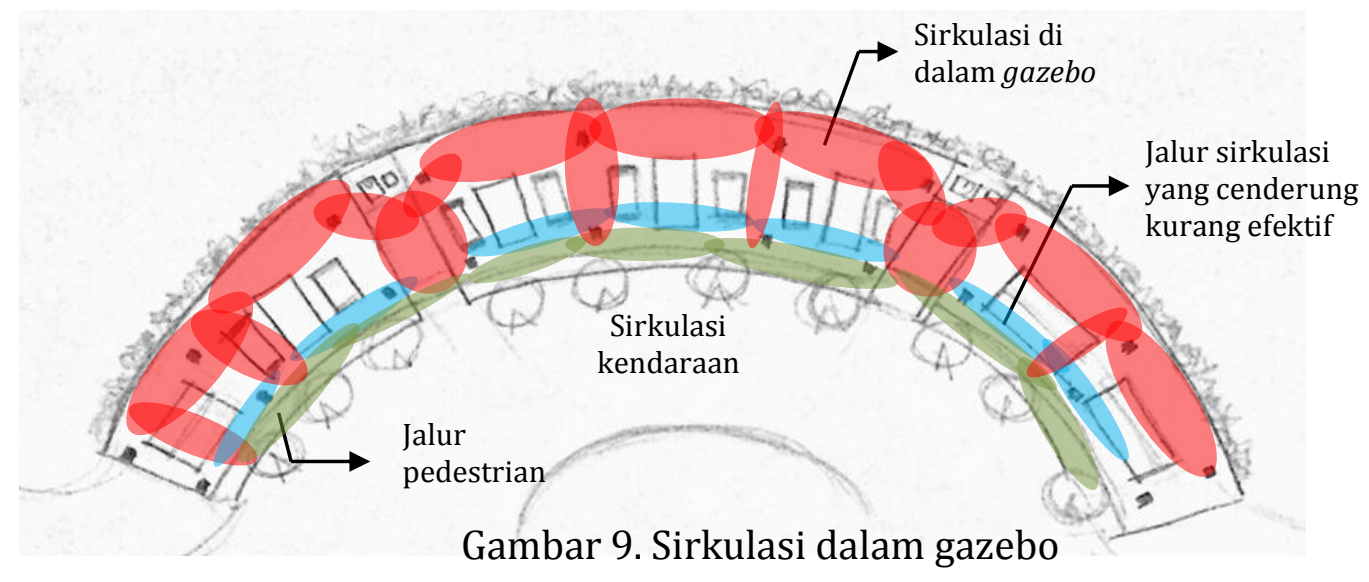

Jalur sirkulasi yang berada di antara kolom dan tatanan furnitur di ruang privat tipe 1 menciptakan sirkulasi yang sempit, sehingga kenyamanannya berkurang. Di depan kolom juga terdapat taman kecil, yang mengurangi efektivitas dan kenyamanan sirkulasi.

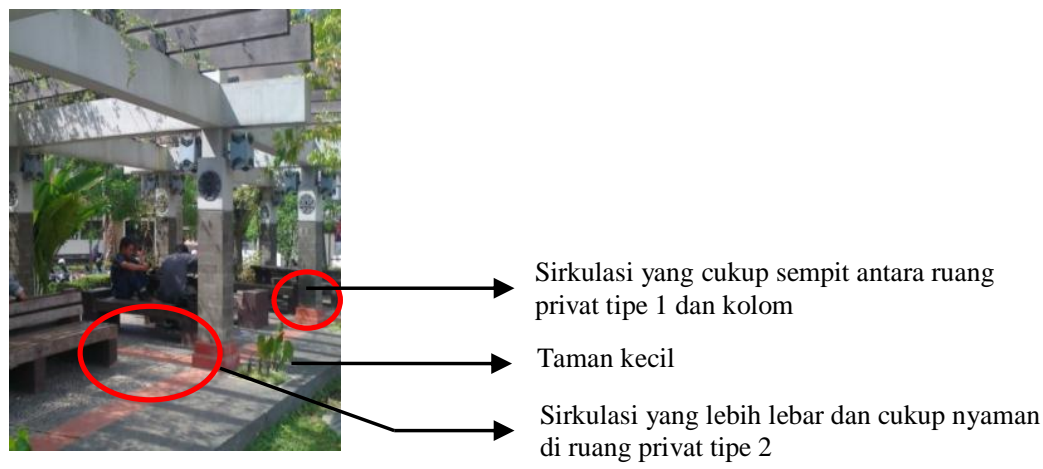

Gambar 10. Analisis sirkulasi ruang privat tipe 1

Berdasarkan observasi didapatkan pula perilaku pengguna ruang terbuka gazebo yang menciptakan ruang privasi sendiri (visual) di dalamnya seperti melakukan aktivitas bercakap-cakap di area sirkulasi sebelah timur dan berbatasan dengan taman. Hal itu dapat mengindikasikan bahwa penilaian cukup baik pada aspek privasi menstimuli munculnya perilaku tersebut untuk memperoleh kenyamanan.
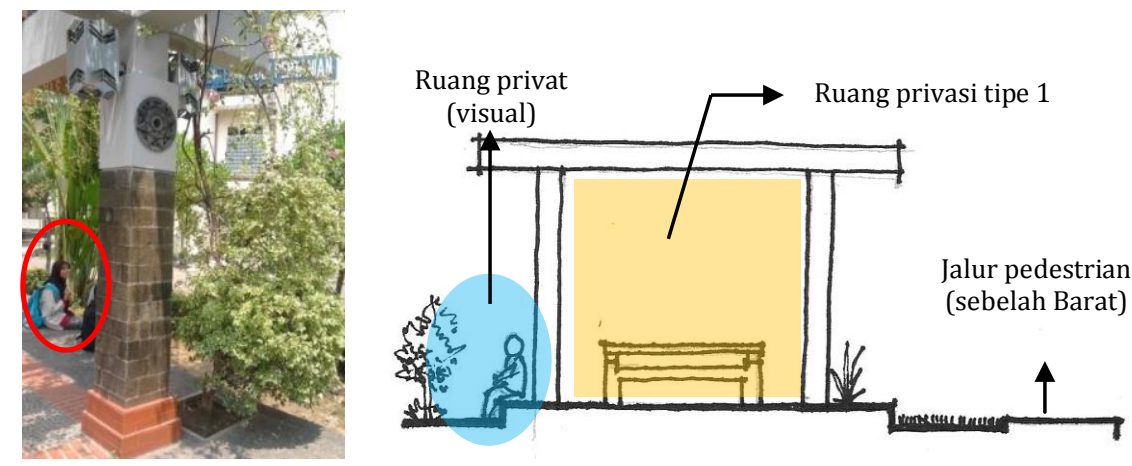

Gambar 11. Perilaku menciptakan ruang privat (visual) 


\section{B. Interaksi}

Gazebo merupakan teritori publik, dimana tatanan furnitur di dalamnya membentuk teritori sekunder bagi para penggunanya. Furnitur, wifi, dan stop kontak di gazebo mendukung kenyamanan berbagai aktivitas di gazebo. 12\% responden menghabiskan waktu 5-8 jam dan 1,3\% menghabiskan waktu 9-12 jam untuk beraktivitas di gazebo.
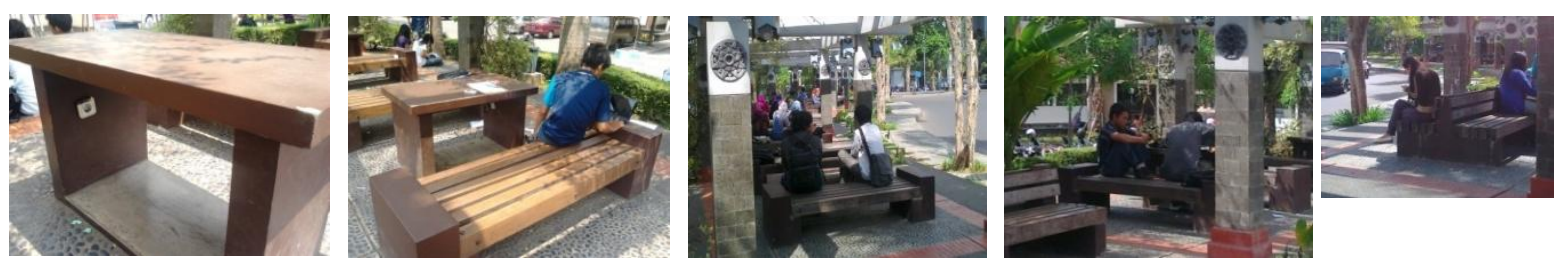

Gambar 12. Detail meja dan ragam aktivitas di gazebo

\section{Persepsi}

Faktor persepsi meliputi kecukupan ruang, cahaya, aroma, suara, cuaca, serta daya tarik estetik. Hasil kuisioner menunjukkan tingkatan penilaian kenyamanan terhadap aspekaspek ruang terbuka tersebut yaitu daya tarik estetik (50,6\%; baik), cuaca (47,5\%; cukup), suara (44,9\%; kurang), cahaya (43,7; baik), aroma (43,7\%; baik), dan kecukupan ruang (39,9\%; cukup). Daya tarik estetik gazebo memiliki persentase penilaian tertinggi. Daya tarik estetik berkaitan dengan estetika gazebo yang diciptakan melalui desain elemenelemen arsitektural serta suasana ruangan (ambience). Elemen-elemen arsitektural gazebo yang memberikan daya tarik estetik antara lain yaitu ornamen di kolom dan lampu hias dengan armatur (rumah lampu) geometris, kolom-balok dan penutup lantai, serta atap.

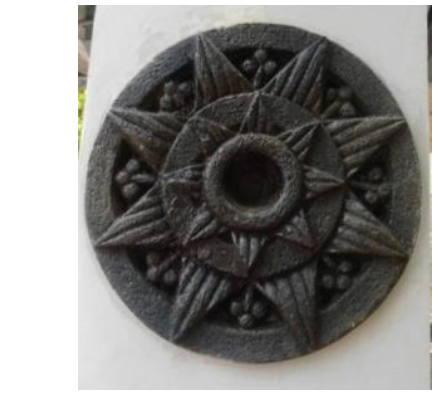

Detail ornamen kolom (menyerupai matahari), terbuat dari pahatan batu candi

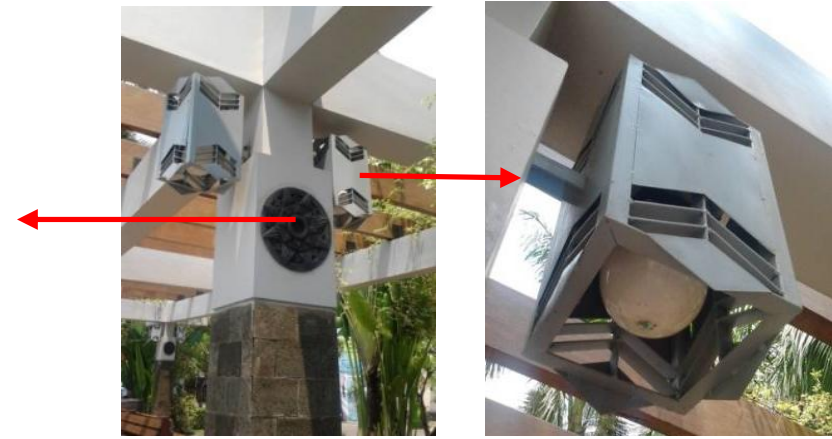

Detail armatur geometris dengan warna monokromatis dengan ornamen kolom

Gambar 13. Ornamen dan lampu hias di kolom sebagai daya tarik estetik gazebo 


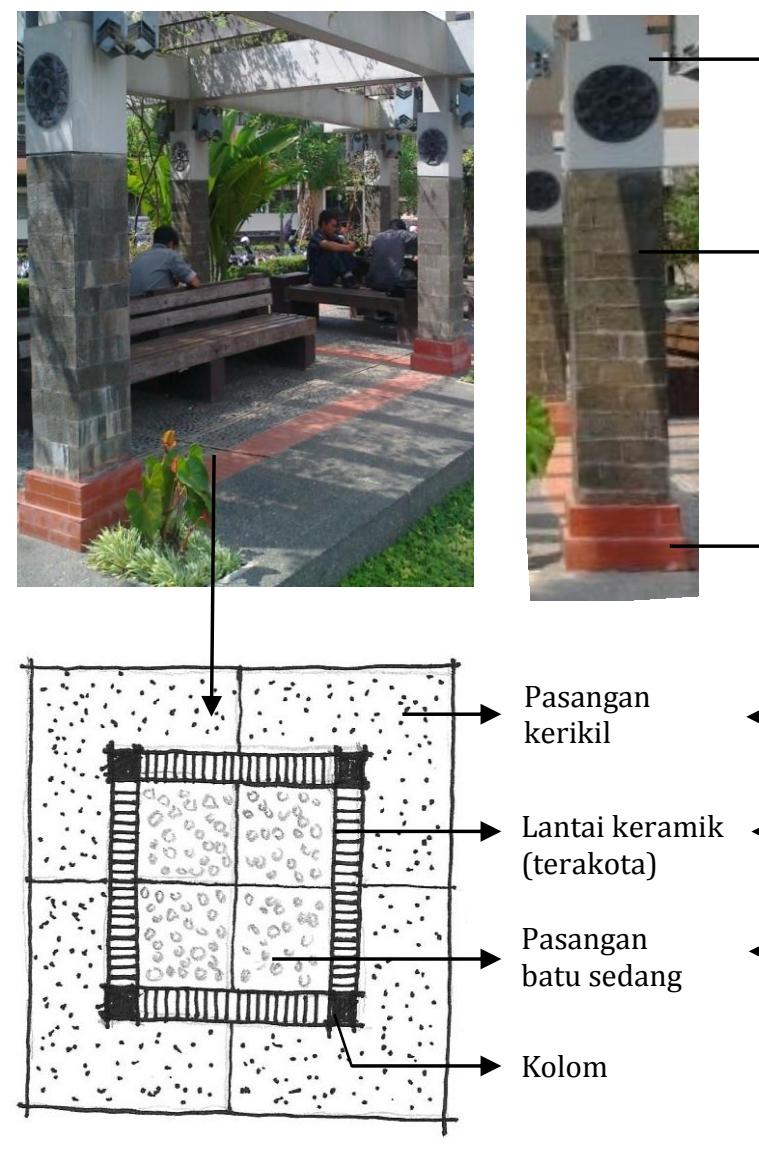

Pola lantai
Kolom bagian atas difinshing

dengan cat berwarna putih tulang

Kolom bagian tengah

difinshing dengan pasangan

lempengan batu berbentuk persegi panjang

Kolom bagian bawah difinshing dengan pasangan keramik berwarna terakota

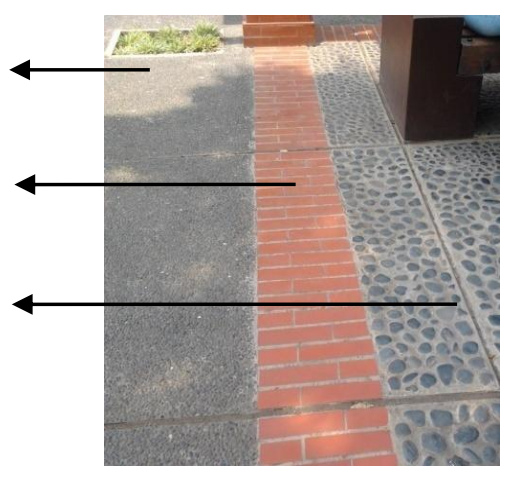

Detail material penutup lantai

Gambar 14. Desain finishing kolom dan lantai sebagai daya tarik estetik gazebo

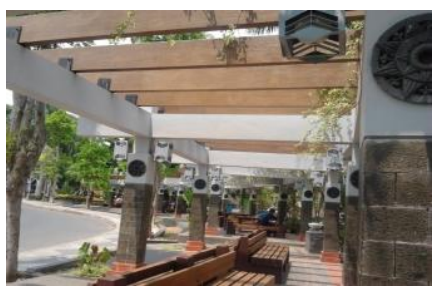

Susunan pergola kayu secara vertikal terhadap bentang gazebo

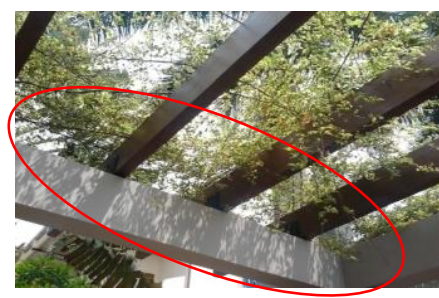

tanaman merambat yang memberikan efek pembayangan

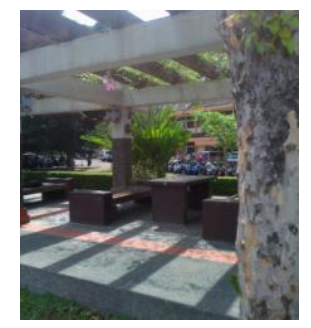

Bayangan pergola dan tanaman merambat

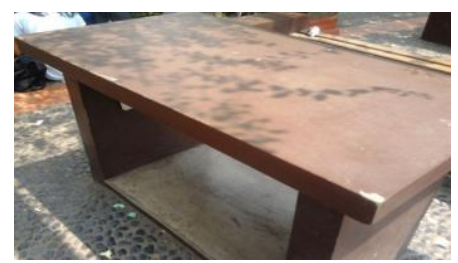

Bayangan tanaman merambat di meja (estetika yang menarik)

Gambar 15. Pergola dan tanaman merambat menciptakan daya tarik estetik gazebo

\section{Orientasi}

Faktor orientasi meliputi penilaian kualitas orientasi terkait kenyamanan view ke luar maupun ke dalam ruang terbuka. Hasil kuisioner menunjukkan 50\% responden menilai aspek orientasi baik. Kondisi gazebo memberikan keleluasaan orientasi pengguna gazebo untuk menikmati view keluar. Lokasi gazebo di Timur tugu jam, didukung karakteristik 
bentuk layout melengkung, serta jarak antar kolom yang cukup lebar, memberikan kenyamanan pengamatan view keluar gazebo khususnya ke arah Barat. Adapun view utama dari arah tersebut yaitu tugu jam (focal point kampus Universitas Brawijaya), lapangan, dan gedung Rektorat. View lainnya yaitu perpustakaan pusat dan gedung kuliah jurusan Ekonomi.
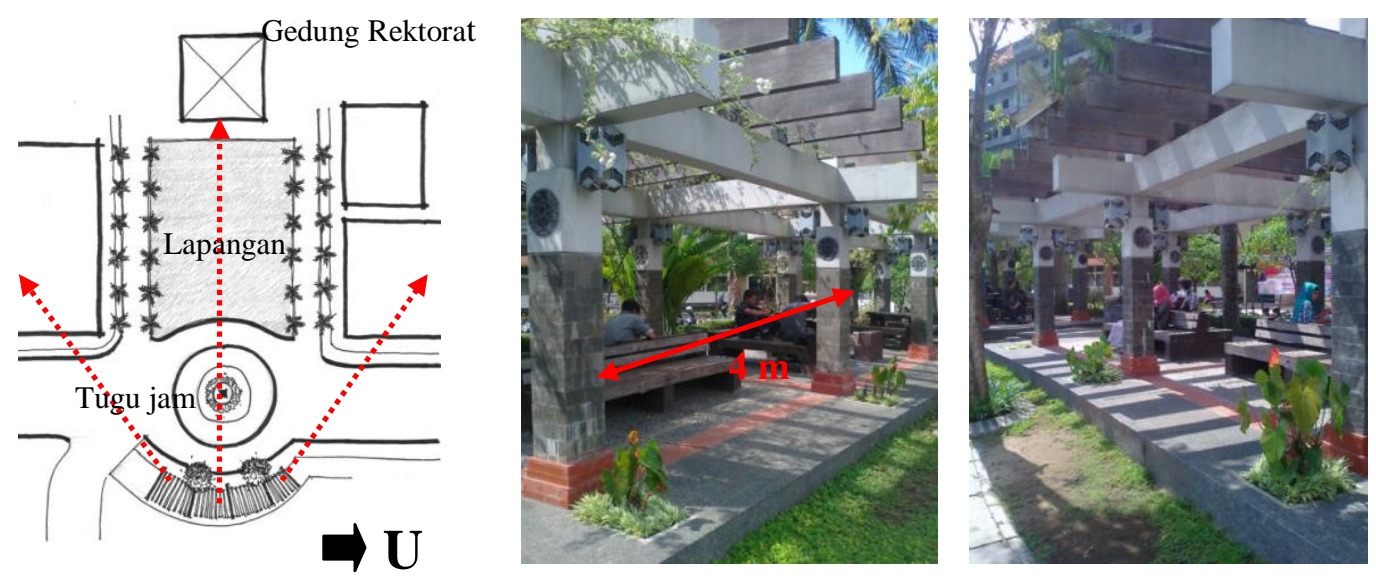

Penempatan pohon di depan kolom, sehingga tidak menghalangi orientasi pengguna gazebo (antara 2 kolom)

Gambar 16. Analisis orientasi/view gazebo

\subsubsection{Evaluasi purna huni lapangan rektorat}

\section{A. Privasi}

Hasil observasi menunjukkan $\pm 20 \%$ area lapangan rektorat ditanami pepohonan bertajuk lebar. Area-area di bawah pepohonan tersebut menciptakan ruang-ruang yang teduh untuk beraktivitas pada pagi, siang, maupun sore hari. Pepohonan turut menciptakan ruangruang privasi. Ruang-ruang privasi menghasilkan penilaian cukup baik.
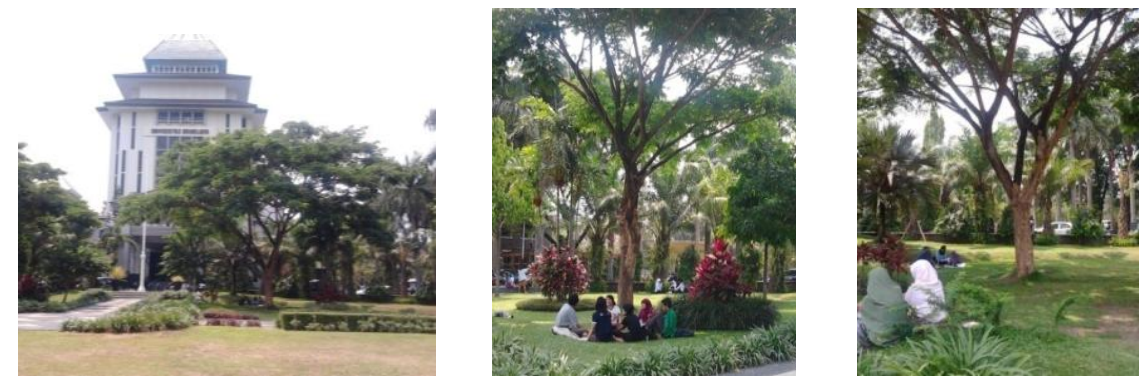

Gambar 17. Analisis aspek privasi di lapangan rektorat

Faktor kemanan dinilai baik, baik kemanan dari masalah kejahatan maupun kendaraan. Badan jalan di sisi Utara dan Selatan digunakan sebagai area parkir. Hal itu memberikan rasa aman bagi para pengguna yang membawa kendaraan bermotor. Kedua sisi lapangan dibatasi pembatas setinggi $\pm 40 \mathrm{~cm}$, sehingga memberikan keleluasaan untuk mengawasi kendaraan atau mengamati kondisi sekitar lapangan rektorat. Faktor keamanan yang 
memiliki persentasi penilaian paling tinggi dalam aspek privasi ini juga didukung oleh adanya jalur pejalan kaki di dalam lapangan rektorat. Jalur khusus tersebut memberikan rasa aman bagi para pengguna ruang terbuka yang melintas di dalam lapangan serta tidak mengganggu aktivitas lainnya seperti olahraga dan belajar bersama.
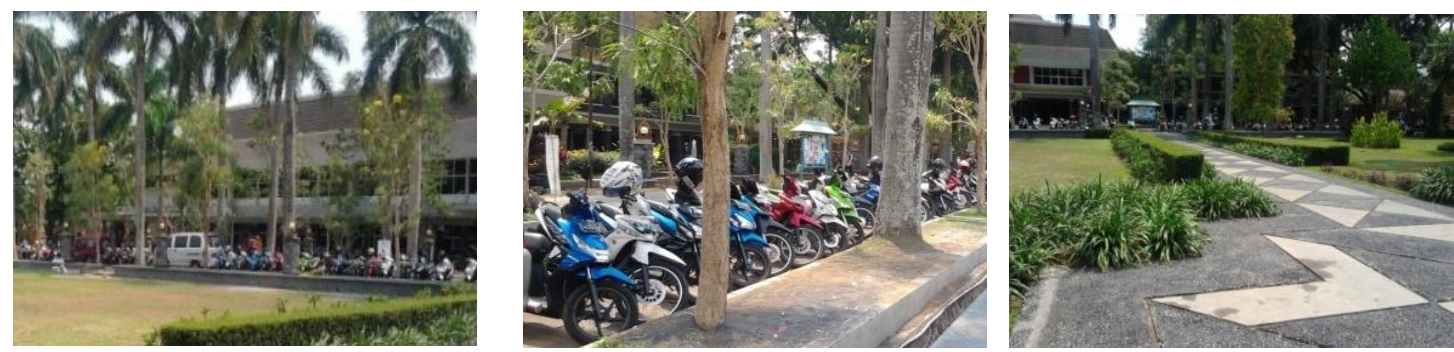

Gambar 18. Area parkir di sekitar lapangan dan jalur pejalan kaki di dalam lapangan rektorat

\section{B. Interaksi}

Faktor interaksi meliputi aspek fleksibilitas guna, dimana hal itu terkait dengan multifungsi ruang di lapangan rektorat. Hasil kuisioner menunjukkan hanya 40,5\% responden yang menilai bahwa fleksibilitas guna ruang lapangan rektorat baik. Persentase tersebut kurang dari 50\%, sehingga hal itu mengindikasikan bahwa aspek fleksibilitas guna masih kurang dapat mengakomodasi kenyamanan pengguna ruang terbuka berupa lapangan rektorat ini. Ruang terbuka berupa lapangan ini tidak memiliki pembatas-pembatas ruang (fisik) di dalamnya sebagaimana halnya yang ada di gazebo. Hasil observasi juga menunjukkan bahwa $80 \%$ area lapangan rektorat berupa hamparan rumput dan terbuka, sehingga aktivitas yang paling banyak berlangsung di dalamnya yaitu olahraga atau di waktu-waktu tertentu digunakan untuk upacara atau kegiatan lomba/pertunjukan musik. Oleh sebab itu, lapangan rektorat kurang memadai kebutuhan pengguna untuk berinteraksi di ruang terbuka kampus Universitas Brawijaya sehari-hari.

\section{Persepsi}

Hasil kuisioner menunjukkan tingkatan persentase dari faktor persepsi ini (tertinggi hingga terendah) yaitu suara (54,8\%, kurang baik), aroma (45,2\%, cukup baik), cuaca $(42,9 \%$, baik), cahaya (40,5\%, baik), daya tarik estetik (38,1\%, baik), dan kecukupan ruang (35,7\%, baik). Dari 6 aspek persepsi tersebut, hanya 17\% yang bernilai lebih dari 50\% yaitu suara, namun kualitasnya kurang baik, sedangkan 83\% aspek persepsi dinilai kurang dari 50\%. Kondisi tersebut menunjukkan bahwa faktor persepsi di lapangan rektorat ini kurang dapat mengakomodasi kenyamanan penggunanya.

Hasil observasi dan penyebaran kuisioner juga menunjukkan bahwa di atas pukul 09.00 12.00 WIB paling banyak aktivitas responden yang berlangsung di lapangan rektorat. Dalam rentang waktu tersebut, cuaca cukup terik dan kendaraan bermotor yang lalu lalang di sekitar lapangan rektorat cukup banyak serta menimbulkan kebisingan. Kondisi tersebut dapat mengurangi kenyamanan pengguna lapangan rektorat yang beraktivitas di dalamnya. Elemen arsitektural maupun vegetasi yang berperan sebagai barrier terhadap kebisingan yang ditimbulkan oleh kendaraan bermotor sangat kurang. Jenis pohon yang mengelilingi lapangan rektorat berupa pohon palm, dimana jenis pohon ini tidak memiliki 
daun yang lebat dan tidak bertajuk lebar. Karakteristik dan penanaman pohon palm dengan jarak $\pm 6 \mathrm{~m}$ antar pohon kurang dapat berperan secara optimal sebagai barrier kebisingan.

\section{Orientasi}

Faktor orientasi meliputi penilaian kualitas orientasi pengguna gazebo terkait dengan kenyamanan view ke luar maupun ke dalam ruang terbuka itu sendiri. Hasil kuisioner menunjukkan 42,9\% responden menilai orientasi di lapangan rektorat baik. Persentase kurang dari 50\%, mengindikasikan aspek orientasi kurang nyaman. Orientasi view yang paling menarik dari dalam lapangan rektorat yaitu tugu jam. View ke arah Utara (gedung widyaloka dan gedung kuliah jurusan Ekonomi) dan Selatan (perpustakaan pusat) memiliki jarak view yang lebih pendek daripada ke arah tugu jam. Kualitas view ke dua sisi tersebut kurang, karena terdapat area parkir kendaraan bermotor. View ke arah Barat adalah ke gedung Rektorat. Potensi view di luar lapangan rektorat didominasi oleh gedunggedung.

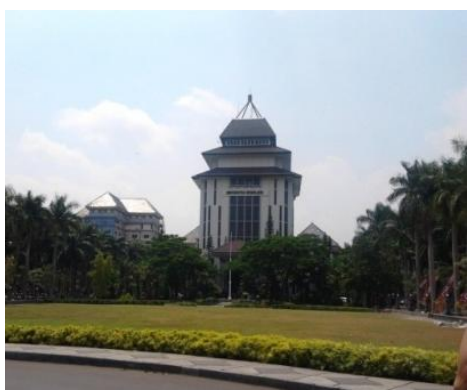

Gedung Rektorat (view di sisi Barat)

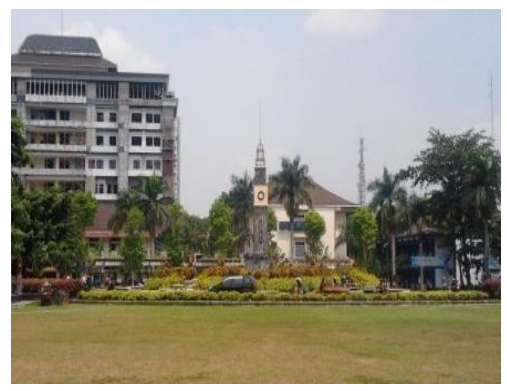

Tugu jam (view di sisi Timur)

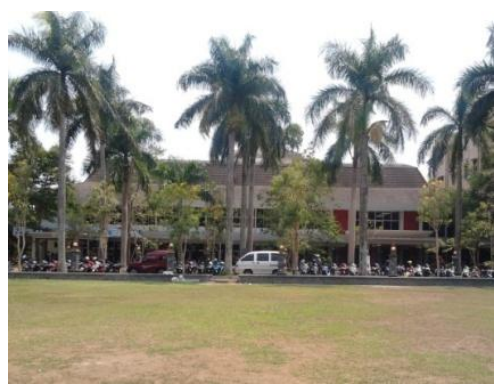

Perpustakaan pusat (view di sisi Selatan)

Gambar 19. Potensi view yang dicapai dari lapangan rektorat

\section{SIMPULAN}

Evaluasi ruang terbuka kampus UB (gazebo dan lapangan rektorat) menerapkan 4 (empat) faktor penilaian utama, yaitu:

1. Privasi, meliputi privasi dan keamanan.

2. Interaksi, meliputi fleksibilitas guna (multifungsi ruang).

3. Persepsi, meliputi kecukupan ruang, cahaya, aroma, suara, cuaca, serta daya tarik estetik.

4. Orientasi, meliputi orientasi.

Gazebo kurang dapat mengakomodasi kenyamanan pengguna ruang terbuka kampus pada aspek privasi dan persepsi. Namun jika dibandingkan dengan lapangan rektorat aspek persepsi di gazebo lebih baik. Aspek interaksi dapat mengakomodasi kenyamanan pengguna gazebo dengan baik, sedangkan aspek orientasi cukup dapat mengakomodasi hal tersebut. Lapangan rektorat masih kurang dapat mengakomodasi kenyamanan pengguna ruang terbuka kampus, baik dari aspek privasi, interaksi, persepsi, maupun orientasi. 


\section{Daftar Pustaka}

Alexander, C. 1977. A Pattern Language: Towns, Buildings, Construction. New York: Oxford University Press.

Altman, I. 1975. Environment and Social Behavior: Privacy, Personal Space, Territory, and Crowding. Monterey, CA: Brooks/Cole.

Amsden, D. J. 2004-2005. Using Behavioral Research to Assist in the Redesign of University Plazas. Planning for Higher Education 33 (2): 31-38.

Bell, P. A., J. D. Fisher, A. Baum, and T. C. Green. 1990 Environmental Psychology. 3rd ed. New York: Holt, Rinehart and Winston.

Bennett, C. 1977. Space for People: Human Factors in Design. New Jersey: Prentice-Hall.

Canter, D. V. 1977. The Psychology of Place. London: Architectural Press.

Carr, S. et al. 1992. Public Space. Cambridge: Cambridge University Press.

Childs, M. C. 2004. Squares: A Public Place Design Guide for Urbanists. Albuquerque: University of New Mexico Press.

Cooper Marcus, C., and C. Francis. 1998. People Places: Design Guidelines for Urban Open Space. 2nd rev. ed. New York: John Wiley \& Sons.

Cooper Marcus, C., and T. Wischemann. 1983. Campus Open Space: An Underutilized Potential. Mimeo. Berkeley: University of California, Berkeley, Department of Landscape Architecture.

Edwards, Brian. University Architecture. 2000. USA. Spon Press.

Hall, E. T. 1966. The Hidden Dimension. New York: Doubleday.

Johnson, L., C. Teeter, and K. Kirshe. 2004. For Those Who Served and Fell. Athens, GA: The University of Georgia Office of University Architects for Facilities Planning.

Kaplan, S., and R. Kaplan. 1982. Cognition and Environment: Functioning in an Uncertain World. New York: Praeger.

Laurens, Marcella. Jonce,2004. Arsitektur dan Perilaku Manusia,Jakarta, Penerbit. P.T. Grasindo.

Lynch, K. 1960. The Image of the City. Cambridge, MA: MIT Press.

Newman, 0. 1972. Defensible Space: Crime Prevention Through Urban Design. New York: Macmillan.

Preiser, W. F. E., H. Z. Rabinowitz, and E. T. White. 1988. Post Occupancy Evaluation. New York: Van Nostrand Reinhold.

Sommer, R. 1969. Personal Space: The Behavioral Basis of Design. Englewood Cliffs, NJ: Prentice-Hall.

Tyre, P. 2005. Professor in Your Pocket. Newsweek, November 28: 46-47.

Whyte, W.H. 1980. The Social Life of Small Urban Spaces. Washington DC: The Conservation Foundation.

Zeisel, J. 2006. Inquiry by Design: Environment/Behavior /Neuroscience in Architecture, Interiors, Landscape, and Planning. Rev. ed. New York: W. W. Norton \& Company.

Zimring, C. M. 1987. Evaluation of Designed Environments: Methods for Post-Occupancy Evaluation. In Methods in Environmental and Behavioral Research, eds. R. Bechtel, R. Marans, and W. Michelson, 270-300. New York: Van Nostrand Reinhold. 